\title{
THE SIGNIFICANCE OF E.A. MARTEL FOR SPELEOLOGY IN SLOVENIA
}

\author{
Andrej Kranjc*
}

\begin{abstract}
Three times Martel visited karst in Carniola: in 1879, 1893 and 1896. The importance of his visits and later publications lies in fact that he informed the francophone public about our karst and caves; his visit stimulated the introduction of new technical means into the then Austrian speleology (folding boat, portable telephone); in 1893 due to his researches Postojnska jama became the longest cave in Europe; public found out about existence of caving society Anthron, which was the first Slovene and Slav society of the kind; he set up the foundations of international speleological co-operation and included into itAustrian speleologists; he informed the public about Putick and his researches of karst underground; unknowingly he helped to introduce the term "karst" into francophone public.
\end{abstract}

Key words: history of speleology, Martel E. A., Slovenia, Kras, Skocjanske jame caves

Edouard-Alfred Martel (1859-1938) founded and was the pioneer of French speleology, he started the tourism on French karst and he"discovered" Cevennes, he accomplished a lot of important discoveries and explorations in other countries, like in Spain, Ireland, England, United States of America and also in Slovenia.

He visited the karst of the former duchy of Carniola (in Martel's time this was one of Austrian hereditary lands, including less than half of the modern Slovenia) three times in 1879, 1893 and 1896. The essence of his visits may be summarised in:

- he informed the francophone public about our country Krasand caves;

- his visit stimulated the introduction of new technical means into the then Austrian speleology (folding boat, portable telephone);

- based on his explorations (1893) Postojnska jama became the longest cave in Europe;

- international public found out about existence of caving society Anthron, which was the first Slovene and Slav society of the kind;

- he pointed out vast (not yet explored) regions of Dinaric karst;

- he set up the foundations of international speleological co-operation and included into it Austrian speleologists.

Details related to his researches in Carniola, in particular in 1893 have been already described and published (Kranjc \& Kranjc 1988), especially at the Symposium "Cent

\footnotetext{
* Karst Research Institute ZRC SAZU,Titov trg 2, SI 6230 Postojna, Slovenia
} 
ans de spéléologie française" in 1988 (Kranjc 1993) and at meeting dedicated to Martel at Mende in 1997(Kranjc 1998).

This is why at this occasion I would like draw the attention to Martel's significance and influence for speleology in Slovenia, not onlyt he impact of his researches but mostly the influence of his publications and his reputation. Since the Symposium "Cent ans de spéléologie française" (Millau 1988), when we last treated this question, a lot of new related to Martel's significance happened in Slovenia:

- The Martel's Chamber in Skocjanske jame was surveyed;

- in 1993 (the centenary of Martel's explorations in Carniola) a Round-Table "Martel and Slovene Karst" was organised in Postojna where seven experts from Slovenia and abroad talked about this matter;

- the 7th volume of Encyclopaedia of Slovenia published the entry "Martel";

Slovene bibliography related to Martel augmented for 16 references.

Martel visited karst of Carniola three times (1879, 1893 and 1896). The first time in 1879 he was a 20 years old boy coming to Postojnska jama with his parents and five other Frenchmen (Stammbuch d. Adelsberger Grotte1879-1892). Unfortunately this was not Postojnska jama which inspired Martel for his later life vocation -speleology. As he himself said: "J'ai dû le goût et la curiosité des phénomènes naturels uniquement à la maîtresse-école des leçons de choses, à quelques voyages d'enfance à Chamonix, en Suisse, aux Pyrénées"(Casteret 1943, p. 23). Not a word about Postojnska jama.

The most important and also the best known Martel's visit to karst of Carniola was his first "mission" in 1893. Describing Kras in his book "Les Abîmes" Martel minutely treats his researches of the underground Pivka with in the Postojnska jama cave system achieved in this year. Helped by Putick and Kraus and accompanied by the Postojnska jama cave guides, Martel explored the underground Pivka from Otoaska jama to Magdalena jama. He saw the siphons in Crna and Pivka jama but he did not succeed to break through any deeper (Mais 1994). Anyway he "lengthened" Postojnska jama for $2 \mathrm{~km}$ and the cave became the longest cave in Europe. In memory of his achievements along the underground Pivka "Martel's Chamber" and "Martel's Breakdown" were named after him.

Related to these researches I would like to mention specially Viljem Putick, Martel's companion over the karst of Carniola, appointed by the Ministry of Agriculture, the count Falkenhayn. In the booklet, prepared by the Slovene geographers for the International Geographical Congress there was chosen as the example from Slovenia - the cross-roads of European scientists - Martel's arrival into Postojna (Kranjc 1996). Martel came from Paris, Putick from Ljubljana, von Hauer who was court councillor came from Vienna to introduce Putick to Martel and Kraus also came from Vienna to help at the explorations. Considering, that later Martel was joined in Postojna by famous cavers from Trieste, such as Pazze,Marinitsch, Müller and Novak we have a right to claim that in 1893 the"blossom of European speleology" gathered here.

Putick, at that time as forestry inspector-assistant belonging to the administration in Villach, successfully worked for seven years already in the underground of Carniola and he also published a lot about his work. When one reads the chapter in Martel's 
comprehensive book "Les Abîmes" (1894) entitled "Karst" (=Kras) containing 57 pages, one is surprised how much data Martel collected related to the region Kras (which, however had a slightly broader meaning for him than the strict area in direct hinterland of Trieste Bay; he regarded Kras covering the whole "Dinaric" karst in Slovenia). Reading his other books and his correspondence one finds out that he had taken most data from the publications of Putick.On several pages of the mentioned chapter there are remarks (abstracts of literature, citations, the most often Putick is quoted) rather longer than the original basic text. Putick did not accompany Martel over Kras in Carniola only but also to Istria. There they succeeded, as the first, to penetrate the siphon in well-known swallow-hole Fojba at Pazin (known to French from the novel Mathias Sandorf of Jules Verne from 1885) (Verne 1972). Thus thanking to Martel and his publications also Putick became much wider known as he would be otherwise, even out of Austro-Hungarian borders or even in non-German speaking countries.

I already mentioned the survey of Skocjanske jame. In Martel's time the cavers of Trieste helped by local "cave workers" already reached the Mrtvo jezero (Dead Lake) which was the final siphon. Immediately after the discovery of the large underground space in Skocjanske jame in August 17, 1890, near to Mrtvo jezero, the chamber was named in honour to Martel the"Martel-Dom". This proves that in that time Martel was already well known in Austrian and Trieste speleological circles and that he was famous too.Obviously, the cavers of Trieste did not less appreciate Martel after his visit. When in 1896 they found on Kras the shaft "Jama na Pauli vrh" (144 m deep) they named it after Martel "Fovea Martel" - today it is called "L'Abisso E.A.Martel" (Guidi \& Cucchi1993).

During his mission in 1893 Martel visited Skocjanske jame also hoping to discover by his folding boat named "Osgood" the continuation or some new passage. Unfortunately the waters were so high after the long lasting rain that the explorers did not dare to launch the boat to the swollen Reka. For better understanding let me remind you that the first explorers needed to overcome the famous 6th Waterfall 8 hours of hard and dangerous work. That his visit would not remain just a sight-seeing trip Martel with the help of balloon with warm air tried to measure the height of the ceiling in some passages (André et al 1997). To measure the height as well other distances in Skocjanske jame is extremely difficult in particular taking into account the roaring river in the bottom of the canyon; this is confirmed by fact that in all this time from 1890 to 1990 the same cave plan was used made on base of explorers from the end of the past century.

We had to wait until the laser ray came into common use before we were able to draw a new and accurate cave plan. By a laser instrument "A.MT. Profiler2000" it was stated among other, that the height of the ceiling is higher than previously thought; in Svetinova dvorana (dvorana = chamber) the ceiling is $104 \mathrm{~m}$ high, in Martelova dvorana the highest measured point lies $146 \mathrm{~m}$ above the Reka river bed. According to new survey the Martel's Chamber is $308 \mathrm{~m}$ long, and at its widest part $123 \mathrm{~m}$ large (the average width is $89 \mathrm{~m}$ ), the average height is $106 \mathrm{~m}$ (the maximal height $146 \mathrm{~m}$ ) (Mihevc 1994). The surface of the largest cross-section is $12,000 \mathrm{~m}^{2}$. As an experiment the volume of this chamber which amounts to 2,2 , million of $\mathrm{m}^{3}$ (Drole 1997) 
was calculated by Winkler's equation. The new cave plan also shows that the so-called chambers of Rinaldini, Putick, Shadeloock and Martel are in fact one huge underground space which was not so well evident from the old plan. This space which can be called "The Great Martel's Chamber" is $630 \mathrm{~m}$ long, up to $126 \mathrm{~m}$ wide and up to $146 \mathrm{~m}$ high. The surface of its ground-plan is $46.000 \mathrm{~m}^{2}$. Its volume calculated on the base of 15 cross-sections by Winkler's equation comes to 2,7 million $\mathrm{m}^{3}$. According to data published in literature (Ford \& Williams 1989) such"Great Martel's Chamber" would be probably the largest known underground space in Europe and maybe also among the largest world-wide.

If we consider a bit the importance of Martel for karst terminology we can compare him with Balthasar Hacquet, Frenchman also, who lived in Carniola from 1766 to 1787, "a stranger among his own people" as he designed himself. Hacquet left Carniola due to "people ignorant and hypocritical in their religion" and went to Lvov as a professor of natural sciences (Wester 1954). He published a book in four volumes entitled "Oryctographia Carniolica" (1778-1789) where he says, that karst is not only on Kras but it extends much further south-eastwards and that people call it "krö" or"karoö". He was too much abreast of the times and almost 100 years were needed to introduce the general term "kras" (karst) (Hohenwart 1830). But when this term was already in a common use appeared Martel wanting to introduce instead the term "limestone relief" (as for example phenomena in limestone, etc.). But, as Hacquet did not succeed to introduce the term "karst", Martel also did not succeed to prevent its use. In spite of his endeavours Martel himself was the man who essentially contributed that the term "karst" was accepted in francophone regions also.

Putick was not the only Martel's companion of Austria. Literature cites that F. Kraus of Vienna bequeathed to Speleological Society in Paris, or to Martel personally, a collection of data on Austrian caves (Cave register).A great deal of these data concerns the caves of Carniola, because Kraus was specially interested in floods on karst poljes of Notranjska.

Before he sent the cave register to France Kraus permitted to A. Gratzy, a member of the Regional Museum of Ljubljana to copy the material related to Carniola and he also published it (Gratzy 1897). For the countries formerly belonging to AustroHungarian Monarchy it would be very interesting to know where this Cave register is now and if it would be possible to look at it. This would be very interesting for the history of speleology, Slovenian in particular. This legacy must surely be contributed to Martel's influence, but from modern point of view this was not the best choice. Yet it shows Martel's intention to internationalise the speleology, as he himself said:"“Enfin, une Société de Spéléologie absolument internationale, fondée à Paris en 1895 , concentre, depuis cette époque, dans ses publications tout ce qui se rapporte actuellement, ou avec un intérêt rétrospectif, aux cavités naturelles du sol en général."(Martel1900). Among the members of the mentioned Société de Spéléologie there were 12 members from the former Austria (Trimmel 1993), Putick included. Member of "Conseil" of this society was also archduke Salvator von HabsburgLothringen, who, in 1896 invited Martel to explore the "Cuevas del Drach", Mallorca (Mader 1994).

Thus we see that Martel's significance is much more important than one would con- 
sider only on the base of his visits and speleological discoveries and the samc can be said for his influence. Thanks to his importance and influence and a little luck, the may be largest underground space in Europe is named after Martel, initiator of French speleology and one of the most important speleologists worldwide. Also for our Kras this coincidence is not bad: the largest underground space, listed in the UNESCO World Natural and Cultural Heritage, is called after the most eminent European speleologist.

\section{REFERENCES}

ANDRÉ D., M. CASTERET , P. CARLIER, A. GAUTIER,G. KALLIATAKIS \& C. ET L. RENOUARD, 1997 - La plume et les gouffres,Correspondance d'Edouard-Alfred Martel. Meyrueis.

CASTERET N., 1943 - E. A. Martel explorateur du monde souterrain. Paris

DROLE F., 1997 - New survey of Skocjanske jame.-Proceedings of the 12th Intern. Congress of Speleology, LaChaux-de-Fonds, 6: 25-28.

FORD D. C. \& WILLIAMS P. W., 1989 - Karst Geomorphology and Hydrology. London.

GRATZY O., 1897 - Die Höhlen und Grotten in Krain.- Mitth. d. Musealvereins f. Krain, H. 5, Jg. X: $133-$ 180.

GUIDI P. \& CUCCHI F., 1993 - E. A. Martel e la speleologia triestina.- Cent ans de spéléologie française,Spelunca Mémoires, Paris, $\mathrm{n}_{\mathrm{i}}$ 17: 89-91.

HACQUET B., 1778 - 1789 - Oryctographia Carniolica oder Physikalische Erdbeschreibung des Herzogthums Krain, Istrien und zum Theil der benachbarten Länder.- I. (1778), II. (1781),III. (1784), IV.(1789), Leipzig.

KRANJC A. \& KRANJC M., 1988 - E. A. Martel na jugoslovanskem krasu.- Naö krö 14, 24-25, 149-158, Sarajevo.

HOHENWART F.J.H., 1830 - Wegweisser für die Wanderer in der berühmten Adelsberger- und Kronprinz Ferdinands-Grotte bey Adelsberg in Krain, herausgegeben von Franz Grafen von Hohenwart.

Als Erklärung der von Herrn Aloys Schaffenrath, k. k. Kreis - Ingenieur in Adelsberg gezeich-

neten Ansichten dieser Grotte. -I. Heft, 1-16, Wien.

KRANJC A., 1993: Martel dans les grottes yougoslaves. - Cent ans de spéléologie française, Spelunca Mémoires, Paris, $n_{i}$ 17: 83-86.

KRANJC A., 1994 - Edouard Alfred Martel and the Slovene karst.- Acta carsologica, Ljubljana, 23: 171 176.

KRANJC A., 1996 - Kras - a gathering point for European scientists. - Slovenia a gateway to Central Europe, Ljubljana: 84 - 91.

KRANJC A., 1998 - Martelov pomen za speleologijo na Slovenskem.- Kras, Ljubljana, 25, 36-38.

MADER B., 1994 - E. A. M rtel in Briefen an Carlo Marchesetti und Erzherzog Ludwig Salvator-- Acta carsologica, Ljubljana,23: 177-190.

MAIS K., 1994 - Kraus und Martel: eine verbindende Achse in Sache Karst.- Acta carsologica, Ljubljana, 23: 191-204.

MARTEL E. A., 1894 - Les Abîmes. Delagrave, Paris.

MARTEL E. A., 1900 - La spéléologie. Coll. Scientia, Paris.

MIHEVC A., 1994 - The Martel's Chamber in Skocjanske jame.- Acta carsologica, Ljubljana, 23, 205-214.

PAZZE P. A., 1893 - Chronik der Section Küstenland des Deutschen und Oesterreichischen Alpenvereins, 1873-1892.Triest. 
STAMMBUCH D. ADELSBERGER GROTTE 1879-1892.- Arhiv Postojnske jame, IZRK ZRC SAZU, Postojna

TRIMMEL H., 1993 - Edouard-Alfred Martel und die Österreichische Speläologie.- Cent ans de spéléologie française, Spelunca Mémoires, Paris, 17: 87-88.

VERNE J., 1972 - Mathias Sandorf.- I-II, Ljubljana.

WESTER J., 1954 - Baltazar Hacquet prvi raziskovalec naöih Alp.Ljubljana.

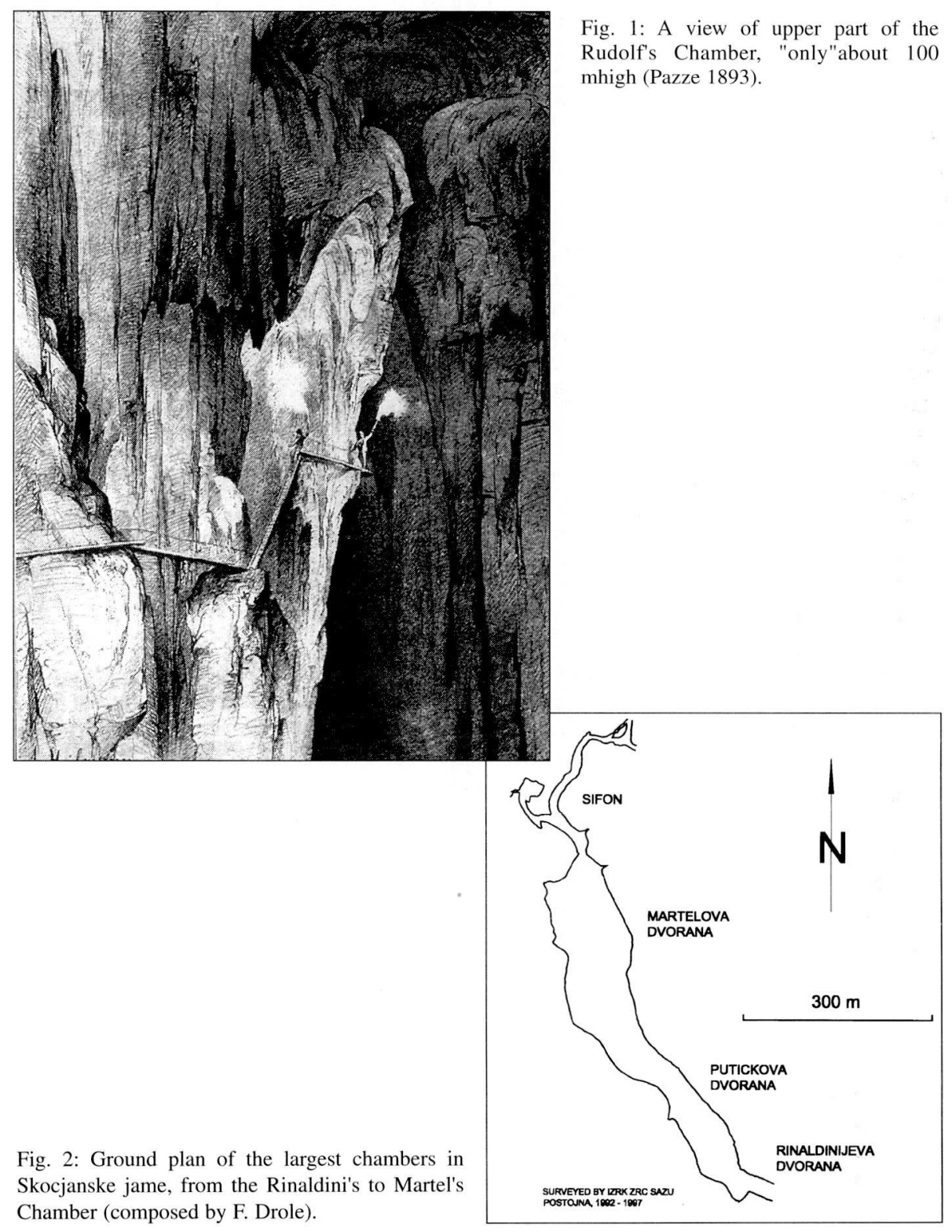




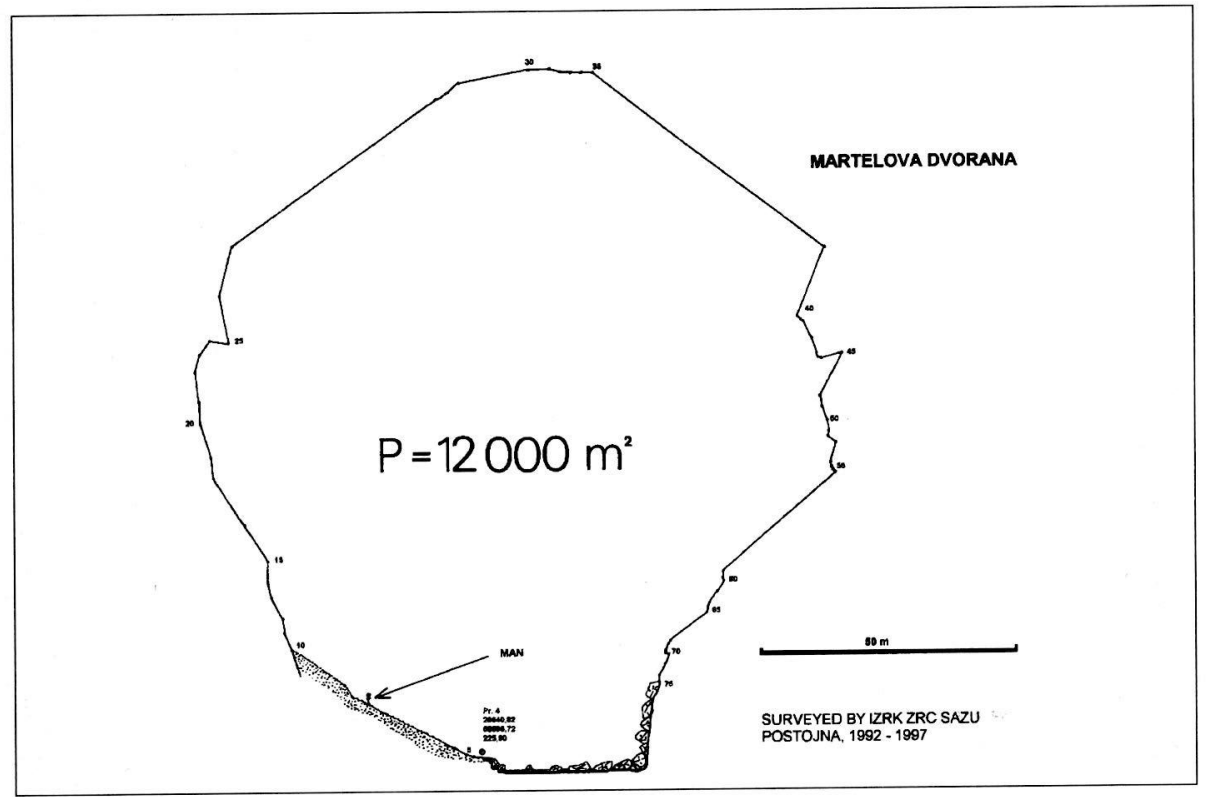

Fig. 3: The largest cross-section of the Martel's Chamber; the highest measured point on the ceiling is 146 m high (Drole 1997). 